\title{
CLERICUS QUIDAM CRIMINE CARNIS LEGAL AND ICONOGRAPHIC INTRICACIES in Causa 15 of Gratian's Decretum
}

Contrary to the common opinion, the Middle Ages never forgot the antiquity. ${ }^{1}$ Since Petrarch the humanists poking around in monastic libraries had been discovering the writings of the ancient authors laboriously copied by the Carolingian scribes in beautiful minuscule. It does not mean that a prince or a bishop, not to mention a scholar, was not aware of the achievements of ancient Greeks or Romans. The importance of the role of antiquity was evident in law, which was revived in Bologna thanks to Irnerius. ${ }^{2}$ One of the most crucial legal issues preoccupying the Medieval society and the one that bore serious legal and political consequences was the question of who should rule the Christian universe. Who should govern Christian Europe which was still taking from the legacy of the Roman emperors? Both, the emperor of the Holy Roman Empire and the pope claimed that dominion. ${ }^{3}$ The dispute between them, with its own dynamics, even despite the accepted compromises - such as the one in Worms in 1122 - has not been solved until modern times. ${ }^{4}$ For the Roman

* Ph.D., the University Library of the Catholic University of Lublin; e-mail: aadamczuk@kul.lublin.pl, ORCID ID: https://orcid.org/0000-0003-4744-1674.

1 S. Wielgus, O micie "ciemnego" średniowiecza i "świattej" nowożytności polemicznie, in: S. Wielgus, Z badań nad średniowieczem, Lublin 1995, pp. 7-49.

2 W. Ullmann, Law and Politics in the Middle Ages. An Introduction to the Sources of Medieval Political Ideas, London 1975, pp. 51-117.

3 G.B. Ladner, The Concepts of "Ecclesia" and "Christianitas" and Their Relation to the Idea of Papal "Plenitudo Potestatis" from Gregory VII to Boniface VIII, in: Sacerdozio e Regno da Gregorio VII a Bonifacio VIII, Roma 1954, p. 54.

4 Historia Kościoła, vol. 2, ed. L.J. Rogier, R. Aubert, M.D. Knowles, Warszawa 1988, p. 144. 
Church the ancient Rome was somewhat problematic. On the one hand it was a source of law, ${ }^{5}$ a model of a great state, an environment in which the great Fathers of the Church educated in the Greek-Roman culture undertook initiative, but on the other hand it was the Rome of Caesars who persecuted Christians.

When organising the canonical law in the mid- $12^{\text {th }}$ century, Gratian, a Camaldolese monk from the monastery in Bologna, was aware of all this. Using the scholastic method, he based his manual Concordia Discordantium Canonum on putting in order a tremendous amount of legal material created by the Church so far. ${ }^{6}$ However, since he lived after the already mentioned Concordat of Worms, and being fully aware of all conflicts between the emperor and the pope, ${ }^{7}$ he did not want to take too much from the legacy of Roman law. It was a conscious decision to reject imperial, i.e. secular legislation which he must have known having worked in the same city and environment as Irnerius and his followers. ${ }^{8}$ Nonetheless, he introduced into his work some of the solutions from Roman law, in some cases taking indirectly from the Corpus Iuris Civilis. ${ }^{9}$ He deliberately chose not to use the solutions proposed by ancient lawyers and their medieval researchers. While applying a typically medieval scholastic method to solve a legal problem, he presented the problem itself as a case, using a very ancient approach. ${ }^{10}$

5 A. Vetulani, Z badań nad prawem rzymskiem w Dekrecie Gracjana, Czasopismo Prawnicze 1935, vol. 30, pp. 119-149; W. Ullmann, Law and Politics in the Middle Ages..., pp. 53-54.

6 S. Kuttner, The Father of the Science of Canon Law, The Jurist 1941, vol. 1, pp. 2-19; S. Kuttner, Graziano: l'uomo e l'opera, in: idem, Gratian and the Schools of Law. 1140-1234, II, London 1983, p. 20; S. Chodorow, Christian Political Theory and Church Politics in the Mid-Twelfth Century. The Ecclesiology of the Gratian's "Decretum", Berkeley-London 1972, pp. 47-64; A. Winroth, The Making of Gratian's "Decretum", Cambridge 2000.

7 S. Chodorow, Magister Gratian and the Problem of "Regnum" and "Sacerdotium" [online], Traditio 1970, vol. 26, pp. 364-381.

8 Ch.H. Haskins, The Renaissance of the Twelfth Century, Cambridge 1927; E. Panofsky, Renaissance and Renascences in Western Art, Stockholm 1960.

9 A. Vetulani, Z badań nad prawem rzymskiem..., pp. 119-149; A. Vetulani, Dekret Gracjana w świetle najnowszych badań, Polonia Sacra 1948, vol. 1, no. 3/4, p. 237.

10 S. Wielgus, Prawo w średniowiecznej kulturze europejskiej, Ethos 1999, vol. 12, no. 1/2, pp. 57-58. 
The very first copies of Gratian's Decretum were already decorated with elaborate initials and figurative miniatures. ${ }^{11}$ Undoubtedly, did the decorations increase the price of respective copies. Practising law has always been, even in the Middle Ages, lucrative enough to allow lawyers to have luxurious hobbies such as bibliophilia. ${ }^{12}$ Figurative miniatures also served a different purpose, though. In times when the passing of knowledge was based on lecture and oral comment on a written text delivered by a professor, they were used as mnemotechnical aid. ${ }^{13}$ It is easier to remember a picture than a text. These miniatures also had a different role. They reflected changes in the legal and political situation related to the place where a given manuscript was created. The same text, depending on time and specific scriptorium, could have been illustrated in a completely dissimilar manner. ${ }^{14}$

This paper deals with the case described and illustrated in Causa XV. The author presents a history of a certain priest:

Clericus quidam crimine carnis lapsus esse perhibetur ante, quam sacerdotalem benedictionem consequeretur. Postquam uero sacerdotium adeptus est, in furorem uersus quendam interfecit. Recuperata uero sanitate apud episcopum accusatur ab ea, cum qua lapsus esse dicitur. Episcopus autem die dominico causam examinat. Sacerdos inficiatur crimen sibi illatum; quorundam clericorum sibi patrocinia querit; illi uero non sine precio sibi patrocinantur; tandem episcopus questionibus confessionem extorquet; demum solus et absque sinodali audientia illum sententia ferit. ${ }^{15}$

A Cleric was reported to have committed a sin of the flesh before having been ordained a priest. After ordination, in a state of anger, he killed a person.

11 A. Melnikas, The Corpus of the Miniatures in the Manuscripts of Decretum Gratiani, vol. 1, Rome 1975, p. 15.

12 Ch. De Hamel, A History of Illuminated Manuscripts, ed. 2, London 1997, p. 108; S. L'Engle, R. Gibbs, Illuminating the Law. Legal Manuscripts in Cambridge Collections, Cambridge 2001.

13 E. Śnieżyńska-Stolot, Tajemnice dekoracji Psałterza Floriańskiego. Z dziejów średniowiecznej koncepcji Uniwersum, Warszawa 1992; eadem, Ikonografia znaków zodiaku i gwiazdozbiorów w średniowieczu, Kraków 1994; S. Lewis, The English Gothic Illuminated Apocalypse, "Lectio Divina" and the Art of Memory, Word and Image 1991, vol. 7, no. 1, pp. 1-32.

14 A. Adamczuk, Miniatury pierwszej części Dekretu Gracjana - "Pars Prima", jako odzwierciedlenie zmian w obrazowaniu stosunków regnum-sacerdotium. Studium ikonologiczne, Archiwa, Biblioteki i Muzea Kościelne 2002, vol. 78, pp. 9-39.

15 Gratianus, Concordia Discordantium Canonum (Decretum), ed. Ae. Friedberg, Corpus Iuris Canonici, vol. 1, Leipzig 1879 (repr. Graz 1959), col. 744. 
Recovering his sanity, he was accused by the woman with whom he had sinned. The bishop examined the case on a Sunday. The priest, however, denied the charge brought against him; he sought out the assistance of some clerics but they were unwilling to furnish him with a defence without a price. Finally, the bishop extorted a confession through torture, then, without a synodal hearing, he passed sentence upon him. ${ }^{16}$

In a compressed way, the author describes a problem with a discipline among clergymen who did not always stand by their vocation. In the history of the Church, and as we can suppose also in seminars today, not all of the candidates for priesthood had relevant moral prerequisites. A good-natured oberfeldkurat Otto Katz from the novel by Jaroslav Hašek is a classic literary example. There are dozens of similar or even worse examples from the Middle Ages and modern times - in Poland that would be for example Piotr Gamrat, the archbishop of Gniezno and primate of Poland in the $16^{\text {th }}$ century. ${ }^{17}$

The main point of the case presented by Gratian is something different. A clergyman, still a deacon, sinned carnally with a woman, and then as an elder, killed a man in anger. He was accused by a woman. It can be assumed that the intercourse was a rape or, adversely, was consented but the man did not withdraw from the earlier commitments. Then, during the consideration of the case, he was tortured. According to the scholastic method, the author asked a few questions to this text. The answers, referring to the legal material created during the centuries of the existence of the Church, provide the solution to the problem. In this case the two most important questions out of the eight asked were quaestio Tertia, an ex mulieris confessione iste sit condempnandus? And quaestio Sexta, an eius confessio cruciatibus sit extorquenda? ${ }^{18}$ Id est if the clergyman can be accused upon the testimony of a woman and if he can be tortured.

Why those two? This conclusion can be drawn from the analysis of miniatures illustrating Causa XV.

The first miniatures illustrating this fragment of Gratian's Decretum, regardless if created in the Cistercian workshops in northern France or in

16 A. Melnikas, The Corpus of the Miniatures..., vol. 2, p. 487.

17 K. Hartleb, Gamrat Piotr, in: Polski stownik biograficzny, vol. 7, ed. W. Kopczyński et al., Kraków 1948-1958, pp. 264-266; P. Nitecki, Biskupi Kościoła w Polsce w latach 965-1999. Stownik biograficzny, ed. 2, Warszawa 2000, pp. 108-109.

18 Gratianus, Concordia Discordantium Canonum..., col. 744. 
Italy, focus on the very moment of committing the crime..$^{19}$ The clergyman, his face twitched with anger, kills a man with a club, an axe, or a cane with a cross and a sharp ending which he pushes into the poor man's eye socket. ${ }^{20}$ Next to him there is a figure of a woman, sometimes with her arms lifted in terror, as a crime witness. Miniatures from two manuscripts from Cambrai ${ }^{21}$ and Berlin ${ }^{22}$ clearly indicate a common source of inspiration or iconographic dependency. With time the iconography develops. In the Q[uidam] initial, from the manuscript Ms. Clm. 17161 kept in Bayerische Staatsbibliothek in Munich, ${ }^{23}$ the clergyman is painted twice - at the moment of committing the manslaughter and before the bishop, being accused by the woman. The motif of double crime of a clergyman is especially strong and dramatic in the early medieval figurative miniatures and initials decorating the manuscripts created in the French scriptoriums, in particular the ones in the northern parts of the country (ill. 1). ${ }^{24}$ If there is a representation of a bishop considering the case, then he is depicted as a figure standing amongst lawyers and priests, one of whom, clearly isolated, would be the accused. ${ }^{25}$

The Italian workshops included two or three episodes of the story within one miniature. It has to be remembered that in Italy, it was the Church that retained and developed legal institutions created by the Romans. Causa XV illustrations created in Italian workshops are similar in stylistics to grand and multifigured series of frescoes, such as the ones in Assisi, but also derive from the decorations of court rooms like the ones we can see in Palazzo della Ragione in Padova.

19 A. Melnikas, The Corpus of the Miniatures..., vol. 2, p. 487.

20 Florence, Biblioteca Laurenziana, Ms. Plut. IV, sin. 1, f. 149, see: A. Melnikas, The Corpus of the Miniatures..., vol. 2, p. 494, ill. 9.

${ }^{21}$ Cambrai, Bibliotheque Municipale, Ms. C. 967, f. 122, see: A. Melnikas, The Corpus of the Miniatures..., vol. 2, p. 496, ill. 14.

${ }_{22}$ Berlin, Staatsbibliothek Preussischer Kulturbesitz, Ms. Lat. Fol. 1, f. 130v, see: A. Melnikas, The Corpus of the Miniatures..., vol. 2, p. 496, ill. 15.

23 A. Melnikas, The Corpus of the Miniatures..., vol. 2, p. 494, ill. 10.

${ }^{24}$ Paris, Bibliothèque nationale, Ms. Lat. 3893, f. 204v, see: A. Melnikas, The Corpus of the Miniatures..., vol. 2, Pl. II.

25 Tours, Bibliothèque Municipal, Ms. 558, f. 191, see: A. Melnikas, The Corpus of the Miniatures..., vol. 2, p. 502, ill. 27. 


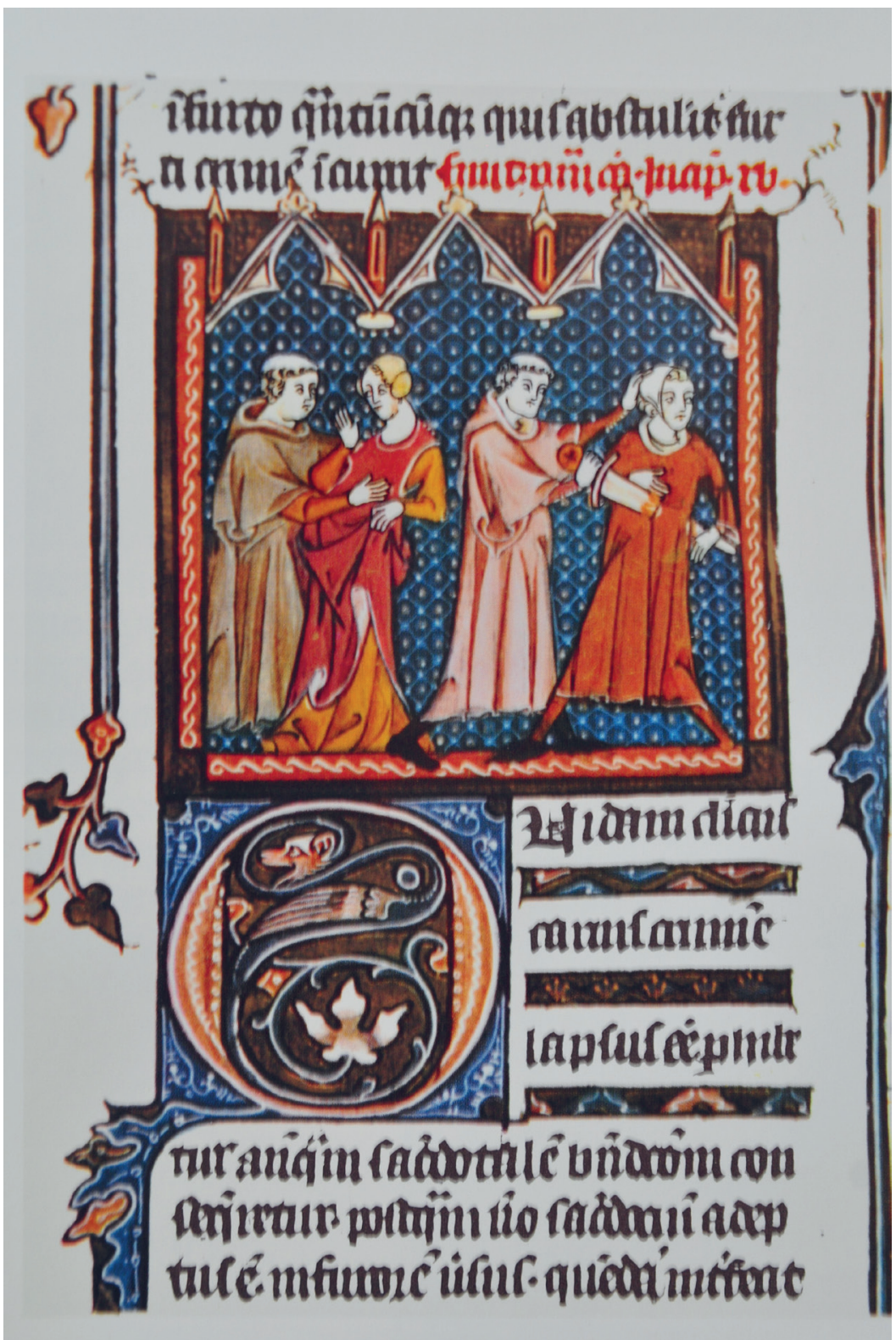

Ill. 1. Decretum Gratiani, Paris, Bibliothèque Nationale, Ms. Lat. 3893, f. 204v

It should be noted that the Italian miniatures emphasise the role of the interrogation. The focal point of the entire composition is the bishop, his importance highlighted with architectural impressive throne. Before the bishop, on a Sunday, the interrogation takes place whereas the crime 
represented by a clergyman's attack with a dagger is presented on the side of the composition (ill. 2). ${ }^{26}$ Before the throne of the bishop-judge there is a woman accusing the priest. She is accompanied by a lawyer. ${ }^{27}$ It is a very strict observance of the text of the Decretum and in this case also adherence to Roman law. Providing the answer to the third question Gratian asserts - referring to the decree of Pope Fabian - that mulieres autem non solum ad sacerdotium, sed nec etiam ad diaconatum provehi possunt, unde nec sacerdotes accusare, nec in eos testificari valent. ${ }^{28}$ The fact that it is impossible to accuse a priest was further supported by Gratian with a quotation from the Diocletian Code:

(C. 15 q. 3 c. 1) "De crimine, quod publicorum fuerit iudiciorum, mulieri accusare non permittitur, nisi certis ex causis, id est si suam suorum que iniuriam persequatur, secundum antiqui iuris statuta tantum, de quibus specialiter eis concessum est, non exacta subscriptione. Unde aditus preses provincie in primis examinabit an tale sit crimen, cuius accusationem mulier subire non prohibetur. ${ }^{29}$

And

(C. 15 q. 3 c. 2) [i]tem in libro Digestorum, Paulus libro II de adulteriis. "Ex eo, quod prohibet lex Iulia de adulteriis testimonium dicere condempnatam mulierem, colligitur etiam mulieres testimonium dicendi in iudicio ius habere". Item de accusationibus et inscriptionibus, lege 1: (§ 1) "Non est permissum mulieri publico iudicio quemquam reum facere, nisi scilicet parentum liberorum que, et patroni et patrone, et eorum filii filie ve, nepotis neptis ve mortem exequatur."

However, there are obviously cases when a wife can press charges before the court (C. 15 q. 3 c. 3) Paulus libro I de adulteriis. "Certis de causis concessa est mulieribus publica accusatio." 30 In general, a woman can obviously have a legal representative and it has to be a man. There is a certain exception however, which is a $15^{\text {th }}$ century code of Italian provenience, in which an accusing woman presses charges in person and in writing against

26 For example: Princeton, University Library (Rare Books and Special Collections), Ms. Garret 97, f. 172v, see: A. Melnikas, The Corpus of the Miniatures..., vol. 2, Pl. V.

${ }^{27}$ For example: Prague, University Library, Ms. Teplá 18, f. 144, see: A. Melnikas, The Corpus of the Miniatures..., vol. 2, p. 511, ill. 43.

28 Gratianus, Concordia Discordantium Canonum..., col. 751.

29 Ibidem.

30 Ibidem. 
a man. ${ }^{31}$ Can it be grounds for claiming a change in the standing of women in Italian city-states, especially considering rapid development of capitalism at this time and in this territory? It should be assumed that miniatures illustrated not only specific legal cases but also the Italian court practice.

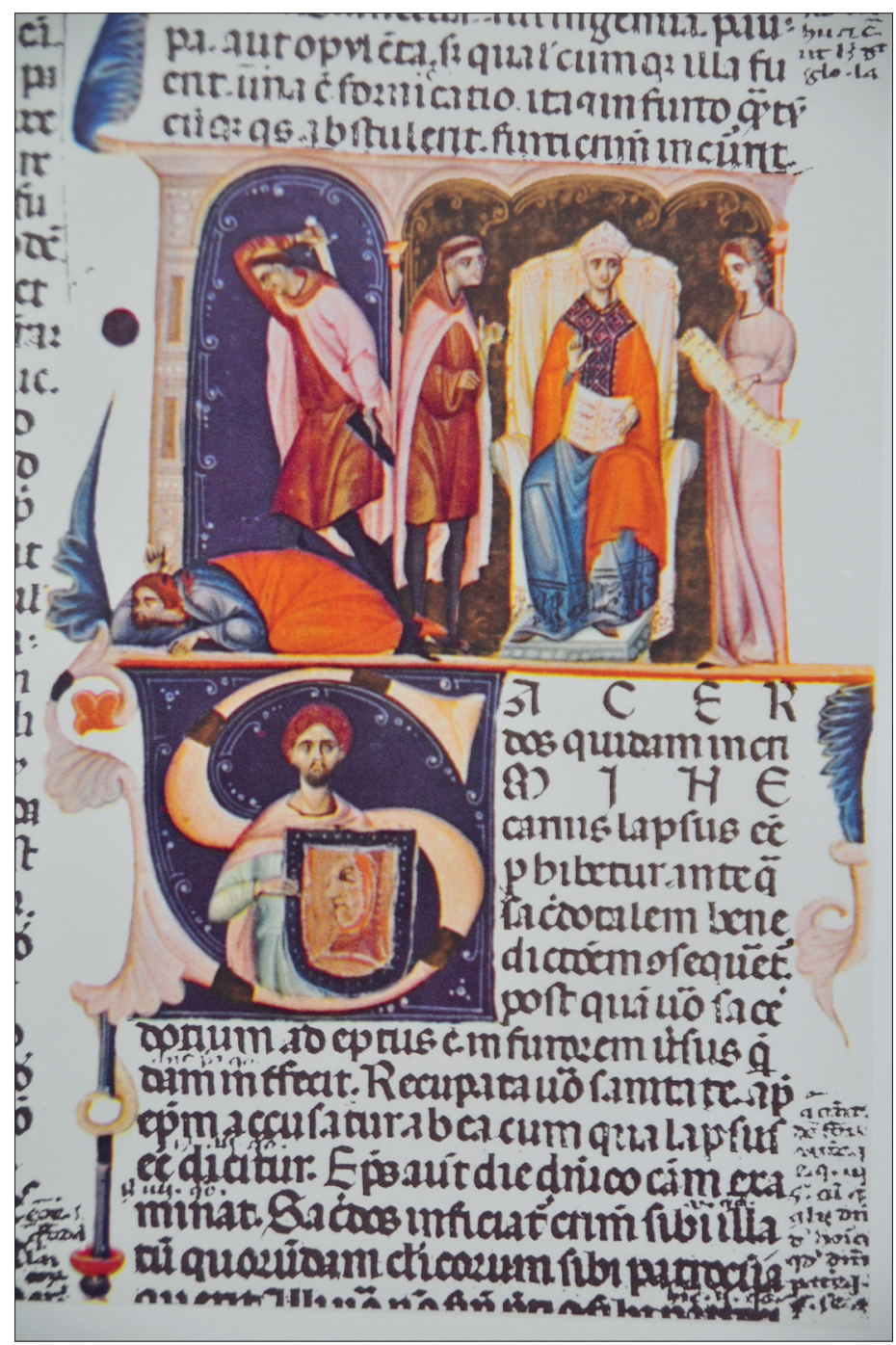

Ill. 2. Decretum Gratiani, Princeton, University Library

(Rare Books and Special Collections), Ms. Garret 97, f. 172v

31 Paris, Bibliothéque Nationale, Ms. Nouv. Acq. Lat. 2508, f. 185, see: A. Melnikas, The Corpus of the Miniatures..., vol. 2, p. 512, ill. 45. 
An interesting group of manuscripts, sharing the same iconography, are the ones created in the south of France, in Toulouse in the second half of the $13^{\text {th }}$ century, i.e. after the Albigensian Crusade. ${ }^{32}$ Gratian's Decretum from the Library of the Catholic University of Lublin also belongs to this group of manuscripts ${ }^{33}$ (ill. 3). The miniatures illustrating Causa XV have a common feature in the composition: apart from the bishop on the throne and a lawyer pointing to a woman kneeling before him, there is also another scene. From the ceiling the tortured clergyman hangs, pulled up by the rope tied around his wrists by an executioner wearing a hat adorned with birdlike colourful wings. ${ }^{34}$ At the executioner's feet lies a victim of clergyman's rage. Such a scene was not terrifying for a medieval viewer; the town's executioner and his methods were well known. Everybody was aware of what they would face if charged and interrogated by a specialist. The Church, however, did not approve of such practices. Gratian, answering the sixth question, affirms strongly referring to Pope Alexander:

(C. 15 q. 6 d.a.c. 1) Quod vero confessio cruciatibus extorquenda non sit, Alexander papa testatur, scribens omnibus orthodoxis: (C. 15 q. 6 c. 1) Ministrorum confessio non sit extorta, sed spontanea. Si sacerdotibus vel auctoribus ecclesie quedam scripture quoquo modo per metum aut fraudem, aut per vim extorte fuerint, vel, ut se liberare possint, quocumque ab eis conscripte aut roborate fuerint ingenio, ad nullum eis preiudicium vel nocumentum valere censemus, neque ullam eos infamiam vel calumpniam, aut a suis sequestrationem bonis umquam, Deo auctore et sanctis apostolis eorum que successoribus, sustinere permittimus. (§ 2) Confessio ergo in talibus non debet extorqueri, sed sponte profiteri. Pessimum enim est de suspicione aut extorta confessione quemquam iudicare, cum magis cordis inspector sit Dominus, quam operis. (§ 3) Non potest autem humano condempnari examine quem Dominus suo reservavit iudicio. Si omnia namque in hoc seculo vindi cata essent, locum divina iudicia non haberent. Item: (§ 4) Est etiam hoc perlatum ad sanctam sedem (quod pudeo dicere, et non solum sacerdotali, sed etiam omni Christiano nomini est inimicum), id est quod nonnulli episcopos vel sacerdotes aut metu conpellunt, aut vi extorquent, aut fraude decipiunt, aliquas confessionis sue in alteram partem, quam debeant, litteras scribere, aut pro suarum non requisitione causarum, aut (quod deterius est) alieni erroris secte scripturas

32 M. Rusins, L'illustration des Décrets de Gratien dans l'enluminure toulousaine au XIV siecle, tese de doctorat sous la direction A. Prache, Paris IV Sorbona, 1996, text unpublished.

33 A. Adamczuk, Prawo i obraz w miniatorstwie średniowiecznym. Iluminowany rękopis Concordia discordantium canonum Gracjana w zbiorach Biblioteki Uniwersyteckiej KUL, Lublin 2009, pp. 114-115.

34 Ibidem, pp. 149-151, ill. 27. 
facere, et propriis manibus roborare, et coram populis recitare atque confiteri. Alios dicunt carceribus et ergastulis retrudi, ut saltem his territi insidiis Domini sacerdotes, suis faveant voluntatibus. Item: (§ 5) Confessio vero in talibus non conpulsa, sed spontanea fieri debet, ipso testante, qui ait: "Ex corde procedunt homicidia, adulteria," et cetera, que sunt ad hec pertinentia. (§ 6) Nec tantum, attendenda sunt que fiant, quantum quo animo fiant. (§ 7) Amplius enim respicit Deus ad cogitationes et spontaneas voluntates, quam ad actus, qui per simplicitatem aut necessitatem fiunt. ${ }^{35}$

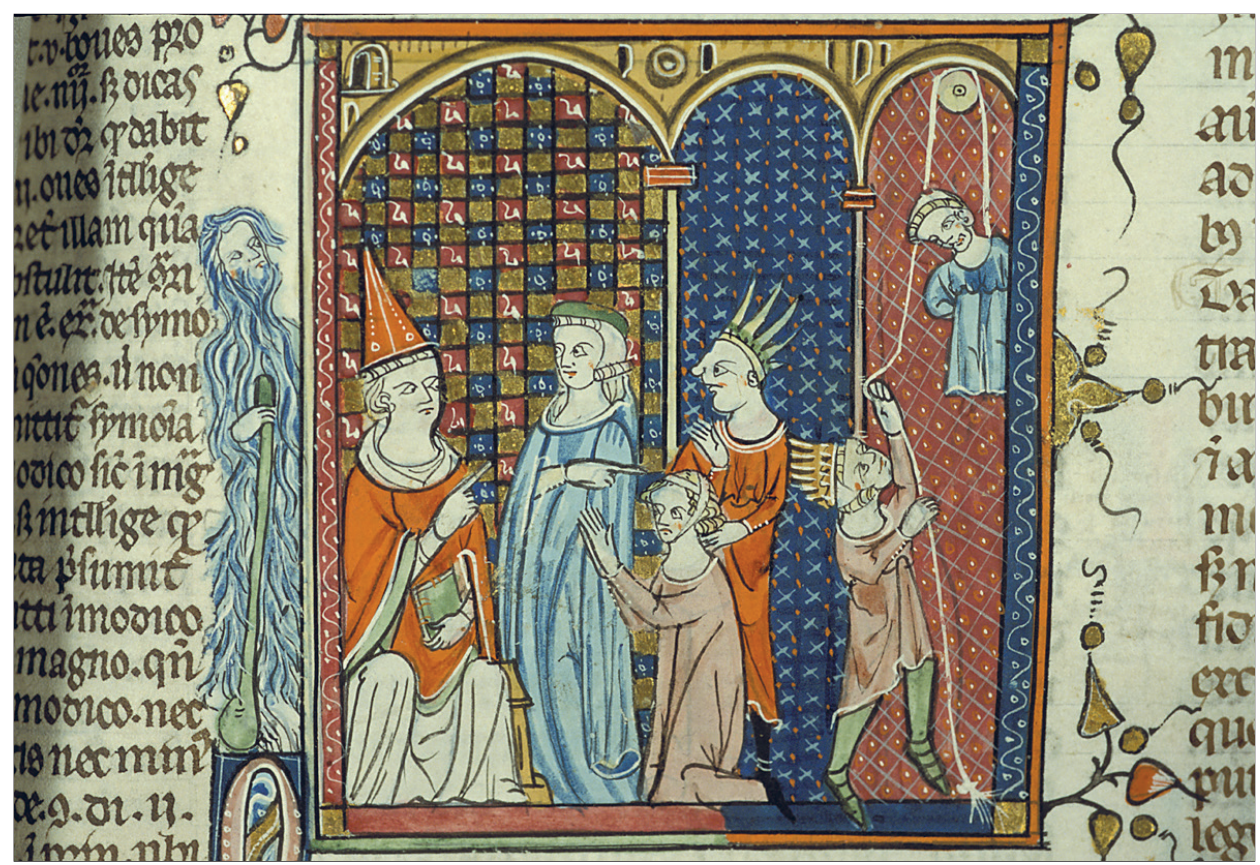

Ill. 3. Decretum Gratiani, Library of the Catholic University of Lublin, Ms. 1, f. 161r

Summing up the examples given above, the mutual relations of Roman and canonical laws can be clearly observed. What should be stressed is the significance of miniatures in the representation of law in the medieval manuscripts. The picture allowed to highlight and emphasise those parts of the text which were important for the person commissioning a given manuscript. It is possible to learn - based on the iconographic analysis of respective scenes - what was important in a particular legal environment (in Italy, or in the south or north of France) while considering specific cases.

35 Gratianus, Concordia Discordantium Canonum..., col. 754. 


\section{Bibliography}

Adamczuk A., Prawo i obraz w miniatorstwie średniowiecznym. Iluminowany rękopis Concordia discordantium canonum Gracjana w zbiorach Biblioteki Uniwersyteckiej KUL, Lublin 2009.

Adamczuk A., Miniatury pierwszej części Dekretu Gracjana - "Pars Prima", jako odzwierciedlenie zmian w obrazowaniu stosunków regnum-sacerdotium. Studium ikonologiczne, Archiwa, Biblioteki i Muzea Kościelne 2002, vol. 78.

Chodorow S., Christian Political Theory and Church Politics in the Mid-Twelfth Century. The Ecclesiology of the Gratian's Decretum, Berkeley-London 1972.

Chodorow S., Magister Gratian and the Problem of "Regnum" and "Sacerdotium", Traditio 1970, vol. 26.

De Hamel Ch., A History of Illuminated Manuscripts, ed. 2, London 1997.

Gratianus, Concordia Discordantium Canonum (Decretum), ed. Ae. Friedberg, Corpus Iuris Canonici, vol. 1, Leipzig 1879 (repr. Graz 1959).

Hartleb K., Gamrat Piotr, in: Polski słownik biograficzny, vol. 7, ed. W. Konopczyński et al., Kraków 1948-1958.

Haskins Ch.H., The Renaissance od the Twelfth Century, Cambridge 1927.

Historia Kościoła, vol. 1-5, ed. L.J. Rogier, R. Aubert, M.D. Knowles, Warszawa 1986-1988.

Kuttner S., Graziano: l'uomo e l'opera, in: S. Kuttner, Gratian and the Schools of Law. 1140-1234, II, London 1983.

Ladner G.B., The Concepts of "Ecclesia" and "Christianitas" and Their Relation to the Idea of Papal "Plenitudo Potestatis" from Gregory VII to Boniface VIII, in: Sacerdozio e Regno da Gregorio VII a Bonifacio VIII, Roma 1954.

Kuttner S., The Father of the Science of Canon Law, The Jurist 1941, vol. 1.

L'Engle S., R. Gibbs, Illuminating the Law: Legal Manuscripts in Cambridge Collections, Cambridge 2001.

Lewis S., The English Gothic Illuminated Apocalypse, "Lectio Divina" and the Art of Memory, Word and Image 1991, vol. 7, no. 1.

Melnikas A., The Corpus of the Miniatures in the Manuscripts of Decretum Gratiani, vol. 1-3, Rome 1975.

Nitecki P., Biskupi Kościoła w Polsce w latach 965-1999. Słownik biograficzny, ed. 2 revised, Warszawa 2000.

Panofsky E., Renaissance and Renascences in Western Art, Stockholm 1960.

Rusins M., L'illustration des Décrets de Gratien dans l'enluminure toulousaine au XIV siecle, tese de doctorat sous la direction A. Prache, Paris IV Sorbona, 1996, text unpublished.

Śnieżyńska-Stolot E., Ikonografia znaków zodiaku i gwiazdozbiorów w średniowieczu, Kraków 1994. 
Śnieżyńska-Stolot E., Tajemnice dekoracji Psałterza Floriańskiego. Z dziejów średniowiecznej koncepcji Uniwersum, Warszawa 1992.

Ullmann W., Law and Politics in the Middle Ages. An Introduction to the Sources of Medieval Political Ideas, London 1975.

Vetulani A., Dekret Gracjana w świetle najnowszych badań, Polonia Sacra 1948, vol. 1, no. $3 / 4$.

Vetulani A., Z badań nad prawem rzymskiem w Dekrecie Gracjana, Czasopismo Prawnicze 1935, vol. 30.

Wielgus S., O micie "ciemnego" średniowiecza i "świattej" nowożytności polemicznie, in: S. Wielgus, Z badan nad średniowieczem, Lublin 1995.

Wielgus S., Prawo w średniowiecznej kulturze europejskiej, Ethos 1999, vol. 12, no. 1/2. Winroth A., The Making of Gratian's "Decretum", Cambridge 2000.

\section{List of Illustrations}

1. Decretum Gratiani, Paris, Bibliothèque Nationale, Ms. Lat. 3893, f. $204 \mathrm{v}$.

2. Decretum Gratiani, Princeton, University Library (Rare Books and Special Collections), Ms. Garret 97, f. 172v.

3. Decretum Gratiani, Library of the Catholic University of Lublin, Ms. 1, f. 161r.

\section{Summary}

The article analyses a problem of the iconography in Causa XV in the Gratian's Decretum. The problem posed by the Bolognese Camaldolese monk firstly concerns the accusation by the woman with whom the priest sinned and secondly the use of torture in the canonical process. In both cases, the author of the Decretum resolves the problem also citing Roman law, among others, by citing Digest or the Diocletian's Code. Miniatures illustrating this Causa, and thus the same text, are different in their iconography depending on the time and place where the specific copy of the manuscript was made. This is mainly due to different, local traditions (e.g. in the medieval Italian countries).

Key words: Gratian's Decretum, Causa XV, illuminations, legal iconography 


\section{CLERICUS QUIDAM CRIMINE CARNIS. ZAWIŁOŚCI PRAWNE I IKONOGRAFICZNE CAUSAE XV Z DEKRETU GRACJANA}

\section{Streszczenie}

Artykuł podejmuje problem ukazania ikonografii Causae XV w Dekrecie Gracjana. Problem postawiony przez bolońskiego kamedułę dotyczy, po pierwsze, oskarżenia przez kobietę, z którą zgrzeszył duchowny, a po drugie, stosowania tortur w procesie kanonicznym. W obu przypadkach autor Dekretu rozstrzyga problem powołując się również na prawo rzymskie: między innymi cytując $D i$ gesta czy Kodeks Dioklecjana. Miniatury ilustrujące tę Causa, a więc i ten sam tekst, różnią się swoją ikonografią w zależności od czasu i miejsca wykonania konkretnego egzemplarza manuskryptu. Wynika to przede wszystkim z odmiennych, lokalnych tradycji prawnych, np. w średniowiecznych państwach włoskich.

Słowa kluczowe: Dekret Gracjana, Causae XV, iluminacje, ikonografia prawna

\section{CLERICUS QUIDAM CRIMINE CARNIS. ПPABOBЫE И ИКОНОГРАФИЧЕСКИЕ СЛОЖНОСТИ САUSAE XV ИЗ УКАЗА ГРАЦИАНА}

\section{Резюме}

В статье рассматривается проблема представления иконографии Causae XV в Указе Грациана. Проблема, которую ставит болонский камальдул, касается, во-первых, обвинения со стороны женщины, с которой духовный согрешил, и, во-вторых, применения пыток в каноническом процессе. В обоих случаях автор Указа решает проблему, ссылаясь также на римское право: в частности, цитируя Дигесты или кодекс Диоклетиана. Миниатюры, иллюстрирующие эту Cause, и, следовательно, один и тот же текст, различаются по своей иконографии в зависимости от времени и места, где была сделана конкретная копия манускрипта. Это объясняется главным образом различными местными правовыми традициями (например, в средневековых итальянских странах).

Ключевые слова: указ Грациана, Causa XV, иллюминация, правовая иконография 
